\title{
Intra-Domiciliary Transmission of Chagas' Disease in Rural Areas of Yucatan Mexico
}

\author{
Eugenia Guzman-Marin1, Karla Y. Acosta-Viana1, Marylin Puerto-Solís', Antonio Ortega-Pacheco², \\ Matilde Jimenez-Coello ${ }^{1}$
}

${ }^{1}$ Cuerpo Académico de Biomedicina de Enfermedades Infecciosas y Parasitarias, CIR “Dr Hideyo Noguchi”, Universidad Autonoma de Yucatan, Merida, Mexico

${ }^{2}$ Cuerpo Académico de Salud Animal, Facultad de Medicina Veterinaria y Zootecnia, Universidad Autónoma de Yucatán,

Merida, México

Email: gmarin@correo.uady.mx

How to cite this paper: Guzman-Marin, E., Acosta-Viana, K.Y., Puerto-Solís, M., Ortega-Pacheco, A. and Jimenez-Coello, M. (2016) Intra-Domiciliary Transmission of Chagas' Disease in Rural Areas of Yucatan Mexico. Open Journal of Epidemiology, 6, 244-255.

http://dx.doi.org/10.4236/ojepi.2016.64024

Received: September 15, 2016

Accepted: November 20, 2016

Published: November 24, 2016

Copyright $\odot 2016$ by authors and Scientific Research Publishing Inc. This work is licensed under the Creative Commons Attribution International License (CC BY 4.0).

http://creativecommons.org/licenses/by/4.0/

\begin{abstract}
With the objective to describe the relationship between $T$. cruzi infection in humans and sinantropic reservoir and vectors in the rural conditions a study was performed in municipalities of the Yucatan state in Mexico. Blood samples from humans, dogs and opossum were taken from the households. Vectors were also collected and the infection and infestation indexes were calculated. Serum samples were evaluated by indirect hemagglutination (IH) and indirect immunofluorescence (IFI) to determine IgG antibodies against Trypanosoma cruzi. The polymerase chain reaction (PCR) was also performed in the samples taken from humans and reservoirs. Blood smears were performed in reservoirs. Sampled humans underwent to an electrocardiographic study to identify functional and conduction alterations of the heart. Household building characteristics were noted. A total of 367 blood samples were collected from people. The presence of IgG antibodies was $16.6 \%$ and $71.0 \%$ at PCR. Electrocardiographic studies revealed that $31 \%$ of patients seropositive to $T$. cruzi have a medical condition. $20.0 \%$ of dogs were seropositive and 68.5 positive to PCR. At the direct detection $13.6 \%$ resulted positive. In opossum $29.1 \%$ were seropositive and $72.9 \%$ positive to PCR. A total of 269 triatomineos were captured and $52.7 \%$ were infected with T. cruzi. The infection and infestation index were $52.4 \%$ and $60.8 \%$ respectively. The presence of adult vectors and their nymph's were more frequently found in households made with wattle roofs ( 45.2 and $73.9 \%$ respectively) than other kind of building materials. Electrocardiographic abnormalities found in positive persons were: Incomplete right bundle branch block (55\%), tachycardia (35\%), old myocardial infarction (5\%) and incomplete block of the left bundle (5\%). This work highlights the importance of comprehensive studies on the transmission of $T$. cruzi in the Yucatan where the link between human infection in synanthropic reservoirs and
\end{abstract}


vectors is established. This information is important to design programs for the epidemiological surveillance and control to break the chain of transmission of the disease.

\section{Keywords}

Trypanosoma cruzi, Vectors, Serology, PCR, Zoonosis.

\section{Introduction}

American Trypanosomiasis also known as Chagas'disease is produced by the flagellated protozoa Trypanosoma cruzi (T. cruzi). It is widely distributed in Latin America [1] [2] It is transmitted to humans by blood-sucking through insects of the Arthropoda phylum, Hexapoda subphylum, Hemiptera order, Reduviidae family, and Triatominae subfamily. [3] Although some 140 species of triatomines (kissing or cone-nosed bugs) have been identified, only a few are competent vectors for $T$ cruzi. The main vectors are Triatoma infestans, Triatoma brasiliensis, and Panstrongylus megistus in the Southern Cone countries, Rhodnius prolixus and Triatoma dimidiata in the Andean Pact countries and parts of Central America, and T dimidiata and Triatoma barberi in Mexico [4]. Domiciliated triatomines are the main agents responsible for the transmission of $T$. cruzi infection in humans. Seven species may be capable of colonising human dwellings in America: $R$. prolixus, $R$. pallescens, T. dimidiata, T. infestans, T. brasiliensis, T. sordida and $P$. megistus. Four of these species present a high degree of adaptation to human housing, including the peridomiciliary area ( $R$. prolixus, $T$. infestans, $T$. dimidiata and T. brasiliensis) [5]. In several studies has been demonstrated that intra-domiciliary transmission of $T$. cruzi, infection has been found strongly associated with the presence of infected dogs in the household, where to own an infected dog increase the risk to become infected approximately 3- to 5-fold [6] [7] [8] [9] [10]. In Mexico, the actual prevalence of the disease is unknown because no official reporting of cases is performed, however Carabin-Lima et al., [11] have estimated that around 5,509,794 persons are infected in the country. According to reports from 15 states of Mexico, there are two major reservoirs, one domestic, the dog (Canis familiaris); and other wild (mainly synanthropic), which includes three species of opossums (Didelphis virginiana, D. marsupialis, and Philander opossum) [12]. Several studies describing the seroprevalence in dogs of Mexico have been conducted and importantly demonstrated a direct correlation with the seropositivity in humans. The high seroprevalence observed in dogs in different areas, suggests that dogs are domestic reservoir hosts and help to maintain human transmission of $T$. cruzi. It has been affirmed that the domestic dog is a risk factor for Chagas disease in Mexico because they can be a permanent and available source of $T$. cruzi infection and significantly enhance transmission of the disease in humans, particularly in cohabitation situations [11]. In Yucatan, the only vector identified in the transmission of $T$. cruzi is Triatoma dimidiata which possess biological ha- 
bits and feeding preferences involved in the epidemiology and transmission to humans [13] [14] [15]. Even the epidemiological conditions are appropriate to the development of the disease in Yucatan, there is no accurate data on the dynamics of domiciliary transmission of Chagas disease, however there are previously studies conducted in the Yucatan peninsula which demonstrate the establishment and maintenance of the parasite as in rural as in urban areas, vector, wild and domestics animals [16] [17] [18]. The objective of this study were to describe the infection frequency of $T$. cruzi in vectors, humans and synanthropic reservoirs in 10 rural villages from Yucatan, Mexico, for a better comprehension of the relationship between prevalence rates in mammal species (dogs and oppossums) and infestation index of households with insect vectors.

\section{Material and Methods}

\subsection{Study Area and Sampled Population}

The study was performed in the Yucatan State of Mexico ( $20^{\circ} 50^{\prime} 00^{\prime \prime} \mathrm{N} 89^{\circ} 00^{\prime} 00^{\prime \prime} \mathrm{O}$.). A random two-stage sampling was performed, where first randomly selected 7 municipalities out of 106 municipalities in the state of Yucatan (Valladolid [ $20^{\circ} 41^{\prime} 22^{\prime \prime} \mathrm{N} 88^{\circ} 12^{\prime} 06^{\prime \prime} \mathrm{O}$ ], Peto [ $20^{\circ} 07^{\prime} 32^{\prime \prime} \mathrm{N} 88^{\circ} 55^{\prime} 17^{\prime \prime} \mathrm{O}$ ], Tekantó [ $21^{\circ} 00^{\prime} 50^{\prime \prime} \mathrm{N} 89^{\circ} 04^{\prime} 50^{\prime \prime O}$ ], Cuzama [ $20^{\circ} 44^{\prime} 00^{\prime \prime} \mathrm{N}$ $89^{\circ} 18^{\prime} 00^{\prime \prime O}$ ], Tixkokob [ $21^{\circ} 00^{\prime} 08^{\prime \prime} \mathrm{N} 89^{\circ} 23^{\prime} 37^{\prime \prime O}$ ], Merida [ $20^{\circ} 58^{\prime} 04^{\prime \prime} \mathrm{N} 89^{\circ} 37^{\prime} 18^{\prime \prime O}$ ] and Hunucma [ $\left.21^{\circ} 10^{\prime} 00^{\prime \prime} \mathrm{N} 90^{\circ} 02^{\prime} 00^{\prime \prime} \mathrm{O}\right]$ ) [19]. Subsequently 2 locations in each municipality were chosen, and then the houses were selected based on the number of streets, trying to cover during sampling to the four cardinal points of each locality. From each municipality 110 households from two locations were selected by a random multistep sampling. In Merida 10 locations were included considering is the capital city and a higher number of households exist. Five household were visited from every selected location and all inhabitants which accepted to participate and potential mammal reservoirs (dog and opossum) were sampled. Triatomines found within the households and around them in a radio of $100 \mathrm{~m}$ were collected. Household building characteristics were recorded. Only persons, who were present in the house at the time of the visits and agreed to participate, were included in the sampling. All participants were adults (>18 - 60 years old). Participants were explained the purpose and procedures of the study and sign a letter of informed consent to be included in the study. All research activities were previously approved and supervised by a registered bioethical committee from Autonomous University of Yucatan.

\subsection{Processing of Samples in Humans}

A blood capillary simple was taken from every inhabitant for serum for serological detection of the agent by mean of indirect hemagglutination (IHA) and indirect immunofluorescence (IFI) and blood were taken in vacutainer tubes with anticoagulant (EDTA) for genomic DNA purification (DNA blood and tissue Kit, Qiagen).

The indirect Hemagglutination test (IHA, Chagatest, Wiener Laboratory) was performed following the manufacturer features. Positive and negative controls were used in each round of tested samples (previously validated and included in the commercial 
diagnostic kit). A sample was considered as positive beside 1:32 dilution reaction. For IFI, a suspension of epimastigotes of $\mathrm{H} 4$ strain was placed on a slide, fixed parasites, and sera from volunteers and controls were diluted 1:32 in PBS and incubated for $30 \mathrm{mi}$ nutes in humid chamber. Subsequently, the slides were washed and incubated with the second anti-human IgG antibody conjugated to fluorescein (F4512, Sigma Aldrich) 1:20 dilution for 30 minutes at $37 \mathrm{C}$. After incubation, the slides were observed in a fluorescence microscope. The presence of a green fluorescence on parasites was considered a positive test. Positive samples were marked with a $+/+++$ according to the degree of fluorescence observed, using as reference a positive control [20]).Genomic DNA from all collected samples were purified (DNA blood and tissue Kit, Qiagen) and evaluated by Polymerase Chain Reaction (PCR) (end point) using as primers oligonucleotids derived from the kinetoplast (KNS1 and KNS2) as previously described by Molina-Garza et al., [21].

\section{Electrocardiographic Studies}

To all the volunteers were performed an electrocardiogram. The electrocardiograph device Cardiovit AT-10 plus (12 channels) was used. Twelve leads were obtained to identify functional and conduction alterations of the heart. The electrocardiograms were analyzed by three cardiologists to determine a diagnosis; special care was placed on rhythm, conduction, and isquemia findings.

\subsection{Processing of Samples in Reservoirs}

All animals (domestic and peridomestic) found in each studied household at the moment of visit were immobilized and sampled to obtain blood and serum. The sample included only the synanthropic domestic animal: dog (Canis familiaris) and synanthropic non domestic animal: opposums (Didelphis marsupialis). Blood collected were processed for direct observation under microscopy (using the stain May Grunwald) and serum was separated by centrifugation at $1200 \mathrm{~g}$ for 10 minutes and aliquoted into eppendorf tubes and frozen at $-20^{\circ} \mathrm{C}$ until use. Serological test in dogs were performed as previously described by Lauricella et al., [22] and Gurtler et al., [10] for IHA and Jimenez-Coello et al., for IFI [23]. Genomic DNA from all collected samples was purified (DNA blood and tissue Kit, Qiagen). The PCR assay was used to evaluate the parasite DNA detection in dogs and opossums following the conditions reported by Molina-Garza et al., [21].

Opossums were capture using Tomahawk traps. Four traps were leave for each household during $48 \mathrm{hr}$ and traps were revised daily (2 times). As bait for traps, portions of chopped fruit of the region were used. Captured animals were sedated and blood sampled. Blood smears were processed for direct detection of the agent by microscopy (adding May Grunwald stain). Serological test in oppossums were performed as previously described by Villagran et al., [24] for IHA and Jansen et al., (1985) [25] for IFI. Genomic DNA from all collected samples were obtained using the DNA blood and tissue Kit, Qiagen and PCR assay was performed in opossums following the conditions described by Molina-Garza et al. [21]. 


\subsection{Processing of Samples in Vectors}

All triatomines captured inside or around the household were studied, to achieve that, a search was conducted using simple hand lanterns inside the house. Each specimen collected was placed in containers for transport, subsequent taxonomic identification and further analysis by direct microscopy and inoculation to mice, with the purpose to isolate T. cruzi. From every specimen fecal content from the intestine was obtained; one part of the content was used for direct detection by microscopy, after diluting the sample in saline solution (0.85\%) and EDTA $(0.05 \%)$ and stained with May Grunwald. Genomic DNA from intestinal content (200 ul of sterile saline solution injected and removed with a syringe to the abdominal region of each parasite) were purified using the DNA blood and tissue Kit, (Qiagen) and PCR endpoint assay was performed with DNA from opossums following the conditions described by Molina-Garza et al., (2007) [19] using $4 \mathrm{ul}$ (at a concentration around $\sim 10 \mathrm{ng} / \mathrm{ul}$ ) of purified DNA as template.

\subsection{Statistical Analysis}

The frequency of seropositive (IFI) and PCR positive cases was determined in humans and reservoirs. In vectors, the infection and infestation index was determined according to the methodology reported (27).

Infection index $=$ No. of positive triatomines $\times 100 /$ number of examined triatomines

Infestation index $=$ No. of positive rooms to triatomines $\times 100 /$ number of visited households

\section{Results}

\subsection{Humans}

A total of 367 blood samples were collected from the inhabitants of the 125 visited households. The presence of IgG antibodies was observed in $11.2 \%$ and $19.9 \%$ for $\mathrm{IH}$ and IFI respectively, corresponding to a general mean of $16.6 \%$. The PCR for those seropositive samples showed $71.0 \%$ of positive cases (Table 1). Electrocardiographic studies revealed that $31 \%$ of patients seropositive to $T$. cruzi $(\mathrm{n}=61$ cases positive by IHA and IFI), have a medical condition including incomplete right bundle branch block ( $\mathrm{n}$ $=11,55 \%)$, tachycardia $(\mathrm{n}=7,35 \%)$, old myocardial infarction $(\mathrm{n}=1,5 \%)$, Chagoma and incomplete block of the left bundle $(n=1,5 \%)$. Fifteen of the persons with an electrocardiographic alteration live with dogs.

Table 1. Frequency of positive cases for by IH, IFI and PCR in humans, dogs and opossums.

\begin{tabular}{cccccc}
\hline \multirow{2}{*}{ Specie } & \multicolumn{5}{c}{ Test } \\
\cline { 2 - 6 } & IH & IFI & IH/IFI & Smears & PCR \\
$n(\%)$ & $n(\%)$ & $7 \%)$ & $n(\%)$ \\
\hline Humans & $41(11.2)$ & $73(19.9)$ & $61(16.6)$ & - & $81(71.0)$ \\
Dogs & $16(22.7)$ & $19(26.3)$ & $7(20.0)$ & $13.6 \%$ & $24(68.5)$ \\
Opossum & $22(27.8)$ & $26(32.9)$ & $48(29.1)$ & $30.7 \%$ & $35(72.9)$ \\
\hline
\end{tabular}




\subsection{Dogs}

A total of 72 dogs were sampled; from those, $22.3 \%$ and $26.7 \%$ were IgG positive to IH and IFI respectively, a general mean of $20.0 \%$. At the direct detection $13.6 \%$ resulted positive. Seropositive samples were evaluated by PCR resulting in $68.5 \%$ of positive cases (Table 1).

\subsection{Opossums}

From the 79 captured opossum (Didelphis virginiana), $27.9 \%$ and $32.9 \%$ were IgG positive to IH and IFI respectively and a mean of $29.1 \%$ for both techniques whereas $30.7 \%$ were positive at direct detection. By PCR, in $72.9 \%$ of analyzed samples, DNA of $T$. cruzi was found (Table 1 ).

\subsection{Vectors}

A total of 269 triatomines were captured from 76 visited households (60.8\%); all of them were from the genus Triatoma, species dimidiata. From all triatomineos 141 (52.7\%) were infected with T. cruzi. The infection and infestation index were $52.4 \%$ and $60.8 \%$ respectively.

\section{Households Building Characteristics}

From the 125 surveyed households, 36 were made of masonry with a tin roof and cement floor (28.8\%), 37 had a tin roof and brick floor (29.6\%) and 52 were made of wattle roof straw and topsoil floor (41.6\%). The presence of adult vectors ad their nymph's were more frequently found in households made with wattle roofs (45.2\%) than in other kind of building (Table 2). In the homes of wattle roof straw with topsoil floors there was a higher risk for the presence of triatomines and thus facilitates the man-vector contact transmission of $T$. cruzi (Table 2). Thirteen persons with electrocardiographic abnormalities were living in wattle roof straw household $s$ and 2 in masonry houses with tin roof, all of them serologically positive and PCR positive. Likewise, from the total infected persons with T. cruzi, 108 (62\%) were living in wattle roof straw and topsoil floors whereas 66 (38\%) were living in masonry houses. Regarding contact with reservoirs 38 (21.8\%) had coexistence positive dogs; 49 (28.1\%) lived in households where infected possums were captured. In total $50 \%$ of positive people were livings with an infected reservoir. The analysis to establish the relationship between the characteristics

Table 2. Household characteristics and presence of vectors (adults \& nymph's).

\begin{tabular}{cccc}
\hline \multirow{2}{*}{ Material } & \multicolumn{2}{c}{ Presence of vectors in visited households } \\
\cline { 2 - 4 } & No. households & $\begin{array}{c}\text { Hoseholds with } \\
\text { adult triatomineos }\end{array}$ & $\begin{array}{c}\text { Households with nimph } \\
\text { triatomineos }\end{array}$ \\
\hline Masonry: tin roof, cement floor & $36(28.8 \%)$ & $18(33.9 \%)$ & $4(17.3 \%)$ \\
Masonery: tin roof brick floors & $37(29.6 \%)$ & $11(20.7 \%)$ & $2(8.6 \%)$ \\
Wattle roof straw and topsoil floor & $52(41.6 \%)$ & $24(45.2 \%)$ & $17(73.9 \%)$ \\
Total & $125(100 \%)$ & $53(42.4 \%)$ & $23(18.4 \%)$
\end{tabular}


of the houses and the presence of triatomines was performed with Chi-square, showing an association between each variable $(p<0.03)$ and the odds ratio was 4.78 for the houses of wattle and daub roof adjusted straw and floor and 3.57 for masonry houses with tin roof, which establishes that there is greater risk in housing wattle and daub for triatomine infestation.

\section{Discussion}

The state of Yucatan is recognized as an endemic area for American trypanosomiasis, because since 1937 the presence of infected vectors and their home was reported. Furthermore, we have identified several human cases and reservoirs in the state. In this research, active transmission of $T$. cruzi is shown in homes where mainly people and dogs that stay at home cohabit. These results are in agreement with many other reports where the dog is recognized as an important risk factor for the domestic transmission of $T$. cruzi and it is therefore necessary to carry out immediate preventive measures to interrupt vector T. cruzi intra-domiciliary transmission, as well as active epidemiologic surveillance programs throughout Mexico and implementation of vector control strategies in disease-endemic areas. [26] [27].

The standard of living in communities studied is low and houses are commonly built of natural materials, also, the original vegetation in this region has been partially destroyed by farming activities, however there are also a lot of empty areas with vegetation used as a Natural ecotope of Triatominae between each house. Is common that insects being of forest habitat penetrate the domestic habitat and increase the probability of transmission to peridomestic animals feed mainly dogs, rats, opossums and human blood [28] [29] [30] [31] [32] Other rate of infection Index in Yucatan Peninsula (in one rural community from Campeche state) has been reported, it was of 38\% [17] just a little lower than $52 \%$ rate we found in this study. Rural communities from Campeche and Yucatan share many ambient conditions, genetics (as in humans as vectors/mammal) and customs from Mayan culture due the proximity. Also shares low income, homes characteristics and families possess high number of domestic animals, without any type of vectorial control measure in the area. For these reasons in this part from southeast of Mexico (Yucatan Peninsula) Chagas disease is and persist well stablished and people living there have an important risk to become infected as in a rural or urban areas.

Dogs are common pets in rural areas and according to our results, they do not sleep inside the house, however, the proximity of these human favors the probability that they are considered as potential sources of infection. Domestic cats are also considered reservoirs for Chagas disease [31], but are less common than dogs in communities. Therefore dogs can occasionally serve as power source vectors are around housing [32] [33] [34] [35]. Similar events occur in different endemic areas of the disease, among which are e.g. Panama and Mexico [10] [28] [34]. Within Mexico, and specifically in Yucatan where the local vector is well identified as intradomiciliary and considering the high infection in the canine population found in our studio (20\%), dogs represent an important reservoir for domestic peridomestic transmission T. cruzi. For example in 
Argentina, bug infection rates showed an increasing trend with the number of seroreactive dogs and an inverse association with the age of the youngest seroreactive dog [10] Also, dogs have also been described as effective sentinels and reservoirs transmission mediated wild triatomines, as these animals can become more easily infected orally ( $T$. cruzi) or by the bite of triatomine before transmission established in the population [35].

Dogs, like humans, developed acute and chronic disease American trypanosomiasis phases, which may be considered to be use as a good model for studies related to experimental pathology [36] [37] [38]. High incidence of infection and infectiousness in dogs and cats combined with suitable exposure patterns to domestic bugs make them primary reservoir hosts and sources of $T$. cruzi infection for householders. A prudent policy to recommend to householders of endemic rural areas is the permanent removal of dogs and cats as well as chickens from bedroom areas [10].

By other hand, infection rate registered in opossum in our study is higher (comparing the PCR results) than previously reported in Didelphis spp. from Yucatan [39]. Our findings also were higher than other reports in southern Mexico (Chiapas), where the seroprevalence in this sylvatic mammal was of $16.6 \%$ [40] and from the western area of Mexico where a seroprevalence of $24 \%$ was reported [41]. Manuscripts indicate than opossum play a key role in the persistence of $T$. cruzi and may be also important agent for the transmission of the disease to humans because of their abundance, the ability to maintain the agent and their proximity with peridomestic and intradomiciliary triatomine bugs when opossums go to houses searching for food. The relevance of this specie is that the developmental cycle of trypomastigote-epimastigote-metacyclic infective trypomastigote, (which usually occurs in the intestine of the triatomine vector), it could take place in the anal odoriferous glands of the opossums, for that reason excreta of opossums may thus transmit $T$. cruzi by contamination, even in areas where insect vectors are not present [42].

\section{Conclusion}

This work highlights the importance of comprehensive studies on the transmission of T. cruzi in the Yucatan where the link between human infection in synanthropic reservoirs and vectors is established. This information is important to design programs for the epidemiological surveillance and control to break the chain of transmission of the disease.

\section{Disclosure Statement}

The authors declare that there is no conflict of interests regarding the publication of this paper.

\section{References}

[1] World Health Organization (2016) Chagas Disease (American Trypanosomiasis). Fact Sheet. http://www.who.int/mediacentre/factsheets/fs340/en/ 
[2] World Health Organization. The Global Burden of Disease Report, 2012.

http://www.who.int/entity/healthinfo/global_burden_disease/GHE_DALY_WHOReg6_200 0_2012.xls

[3] Moncayo, A. (2003) Chagas Disease: Current Epidemiological Trends after the Interruption of Vectorial and Transfusional Transmission in the Southern Cone Countries. Memórias do Instituto Oswaldo Cruz, 98, 577-591. http://dx.doi.org/10.1590/S0074-02762003000500001

[4] Rassi, A. and de Rezende, J.M. (2012) American Trypanosomiasis (Chagas Disease). Infectious Disease Clinics of North America, 26, 275-291. http://dx.doi.org/10.1016/j.idc.2012.03.002

[5] Guhl, F., Pinto, N. and Aguilera, G. (2009) Sylvatic Triatominae: A New Challenge in Vector Control Transmission. Memorias do Instituto Oswaldo Cruz, 104, 71-75.

http://dx.doi.org/10.1590/S0074-02762009000900012

[6] Gürtler, R.E., Cécere, M.C., Rubel, D.N., Petersen, R.M., Schweigmann, N.J., Lauricella, M.A., et al. (1991) Chagas Disease in North-West Argentina: Infected Dogs as a Risk Factor for the Domestic Transmission of Trypanosoma cruzi. Transactions of the Royal Society of Tropical Medicine and Hygiene, 85, 741-745. http://dx.doi.org/10.1016/0035-9203(91)90440-A

[7] Gürtler, R.E., Cecere, M.C., Petersen, R.M., Rubel, D.N. and Schweigmann, N.J. (1993) Chagas Disease in North-West Argentina: Association between Trypanosoma cruzi Parasitaemia in Dogs and Cats and Infection Rates in Domestic Triatoma infestans. Transactions of the Royal Society of Tropical Medicine and Hygiene, 87, 12-15. http://dx.doi.org/10.1016/0035-9203(93)90400-K

[8] Cohen, J.E. and Gürtler, R.E. (2001) Modeling Household Transmission of American Trypanosomiasis. Science, 293, 694-698. http://dx.doi.org/10.1126/science.1060638

[9] Estrada-Franco, J.G., Bhatia, V., Diaz-Albiter, H., Ochoa-Garcia, L., Barbabosa, A., Vazquez-Chagoyan, J.C., Martinez-Perez, M.A., Guzman-Bracho, C. and Garg, N. (2006) Human Trypanosoma cruzi Infection and Seropositivity in Dogs, Mexico. Emerging Infectious Disease, 12, 624-630. http://dx.doi.org/10.3201/eid1204.050450

[10] Gürtler, R.E., Cecere, M.C., Lauricella, M.A., Cardinal, M.V., Kitron, U. and Cohen, J.E. (2007) Domestic Dogs and Cats as Sources of Trypanosoma cruzi Infection in Rural Northwestern Argentina. Parasitology, 134, 69-82. http://dx.doi.org/10.1017/S0031182006001259

[11] Carabarin-Lima, A., González-Vázquez, M.C., Rodríguez-Morales, O., Baylón-Pacheco, L., Rosales-Encina, J.L., Reyes-López, P.A. and Arce-Fonseca, M. (2013) Chagas Disease (American Trypanosomiasis) in Mexico: An Update. Acta Tropica, 127, 126-135. http://dx.doi.org/10.1016/j.actatropica.2013.04.007

[12] Cruz-Reyes, A. and Pickering-López, J.M. (2006) Chagas Disease in Mexico: An Analysis of Geographical Distribution during the Past 76 Years-A Review. Memórias do Instituto Oswaldo Cruz, 101, 345-354. http://dx.doi.org/10.1590/S0074-02762006000400001

[13] Quintal, R.E. and Polanco, G.G. (1977) Feeding Preferences of Triatoma Dimidiate Maculipennis in Yucatan, Mexico. The American Journal of Tropical Medicine and Hygiene, 26, 176-178.

[14] Guzmán-Marín, E., Barrera-Pérez, M., Rodríguez-Félix, M.E., Escobedo-Ortegón J. and Zavala-Velázquez, J. (1991) Índices entomológicos de Triatoma dimidiata en el estado de Yucatán. Revista Biomédica, 2, 20-29.

[15] Guzmán-Marín, E., Barrera-Pérez, M., Rodríguez-Félix M.E. and Zavala-Velázquez, J. (1992) Hábitos biológicos de Triatoma dimidiata en el estado de Yucatán México. Revista Biomédica, 3, 125-131. 
[16] López-Cancino, S.A., Tun-Ku, E., De la Cruz-Felix, H.K., Ibarra-Cerdeña, C.N., Izeta-Alberdi, A., Pech-May, A., Mazariegos-Hidalgo, C.J., Valdez-Tah, A. and Ramsey, J.M. (2015) Landscape Ecology of Trypanosoma cruzi in the Southern Yucatan Peninsula. Acta Tropica, 151, 58-72. http://dx.doi.org/10.1016/j.actatropica.2015.07.021

[17] Monteon, V., Alducin, C., Hernández, J., Ramos-Ligonio, A. and Lopez, R. (2013) High Frequency of Human Blood in Triatoma dimidiata Captured Inside Dwellings in a Rural Community in the Yucatan Peninsula, Mexico, but Low Antibody Seroprevalence and Electrocardiographic Findings Compatible with Chagas Disease in Humans. American Journal of Tropical Medicine and Hygiene, 88, 566-571. http://dx.doi.org/10.4269/ajtmh.12-0583

[18] Balan, L.U., Yerbes, I.M., Piña, M.A., Balmes, J., Pascual, A., Hernández, O., Lopez, R. and Monteón, V. (2011) Higher Seroprevalence of Trypanosoma cruzi Infection in Dogs than in Humans in an Urban Area of Campeche, Mexico. Vector Borne and Zoonotic Diseases, 11, 843-844. http://dx.doi.org/10.1089/vbz.2010.0039

[19] Municipios en Yucatan (2016) http://www.municipios.mx/yucatan/

[20] Ramos-Ligonio, A., Ramírez-Sánchez, M.E., González-Hernández, J.C., Rosales-Encina, J.L. and López-Monteon, A. (2006) Prevalencia de anticuerpos contra Trypanosoma cruzi en donadores de sangre del IMSS, Orizaba, Veracruz, México. Salud Pública de México, 48, 13-21. http://dx.doi.org/10.1590/S0036-36342006000100004

[21] Molina-Garza, Z.J., Rosales-Encina, J.L., Galaviz-Silva, L. and Molina-Garza, D. (2007) Prevalencia de Trypanosoma cruzi en triatominos silvestres de Nuevo León, México. Salud Pública de México, 49, 37-44. http://dx.doi.org/10.1590/S0036-36342007000100006

[22] Lauricella, M.A., Castañera, M.B., Gürtler, R.E. and Segura, E.L. (1998) Immunodiagnosis of Trypanosoma cruzi (Chagas' Disease) Infection in Naturally Infected Dogs. Memorias do Instituto Oswaldo Cruz, 93, 501-507. http://dx.doi.org/10.1590/S0074-02761998000400016

[23] Jimenez-Coello, M., Poot-Cob, M., Ortega-Pacheco, A., Guzman-Marin, E., Ramos-Ligonio, A., Sauri-Arceo, C.H. and Acosta-Viana, K.Y. (2008) American Trypanosomiasis in Dogs from an Urban and Rural Area of Yucatan, Mexico. Vector Borne and Zoonotic Diseases, 8, 755-761. http://dx.doi.org/10.1089/vbz.2007.0224

[24] Villagrán, M.E., Martínez-Ibarra, J.A. and Diego, J.A.D. (2011) Pathological Alterations and Prevalence of Trypanosoma cruzi in Opossums from Western Mexico. Boletín de Malariología y Salud Ambiental, L1, 87-88.

[25] Jansen, A.M., Moriearty, P.L., Castro, B.G. and Deane, M.P. (1985) Trypanosoma cruzi in the Opossum Didelphis marsupialis: An Indirect Fluorescent Antibody Test for the Diagnosis and Follow-Up of Natural and Experimental Infections. Transactions of the Royal Society of Tropical Medicine and Hygiene, 79, 474-477. http://dx.doi.org/10.1016/0035-9203(85)90069-0

[26] Zavala-Velázquez, J., Barrera-Pérez, M., Rodríguez-Félix, M.E., Guzmán-Marín, E. and Ruíz-Piña, H. (1996) Infection by Trypanosoma cruzi in Mammals in Yucatan, Mexico: A Serological and Parasitological Study. Revista do Instituto de Medicina Tropical Sao Paulo, 38, 289-292. http://dx.doi.org/10.1590/S0036-46651996000400009

[27] Silveira, A.C., Fazro, R.D. and Correira, M.M.H. (1984) Risk Measures of Domestic Transmission of Chagas' Disease through a New Entomological Indicator. Memorias do Instituto Oswaldo Cruz, 29, 113-115. http://dx.doi.org/10.1590/S0074-02761984000500021

[28] Ramsey, J.M., Gutiérrez-Cabrera, A.E., Salgado-Ramirez, L., Peterson, A.T., Sanchez-Cordero, V. and Ibarra-Cerdeña, C.N. (2012) Ecological Connectivity of Trypanosoma cruzi Reservoirs and Triatoma pallidipennis Hosts in an Anthropogenic Landscape with Endemic Chagas Disease. PLoS ONE, 7, e46013. http://dx.doi.org/10.1371/journal.pone.0046013 
[29] Samudio, F., Ortega-Barría, E., Saldaña, A. and Calzada, J. (2007) Predominance of Trypanosoma cruzi I among Panamanian Sylvatic Isolates. Acta Tropicaica, 101, 178-181. http://dx.doi.org/10.1016/j.actatropica.2006.12.008

[30] Pineda, V., Montalvo, E., Alvarez, D., Santamaría, A.M., Calzada, J.E. and Saldaña, A. (2008) Feeding Sources and Trypanosome Infection Index of Rhodnius pallescens in a Chagas Disease Endemic Area of Amador County, Panama. Revista do Instituto de Medicina Tropical Sao Paulo, 50, 113-116. http://dx.doi.org/10.1590/s0036-46652008000200009

[31] Jiménez-Coello, M., Acosta-Viana, K.Y., Guzman-Marin, E., Gomez-Rios, A. and OrtegaPacheco, A. (2012) Epidemiological Survey of Trypanosoma cruzi Infection in Domestic Owned Cats from the Tropical Southeast of Mexico. Zoonoses and Public Health, 59, 102109. http://dx.doi.org/10.1111/j.1863-2378.2012.01463.x

[32] Jansen, A.M. and Roque, A.L.R. (2010) Domestic and Wild Mammalian Reservoirs. In: Telleria, J. and Tibayrenc, M., Eds., American Trypanosomiasis: Chagas Disease One Hundred Years of Research, Elsevier, London, 249-276.

http://dx.doi.org/10.1016/B978-0-12-384876-5.00011-3

[33] Roque, A.L., Xavier, S.C., da Rocha, M.G., Duarte, A.C., D’Andrea, P.S. and Jansen, A.M. (2008) Trypanosoma cruzi Transmission Cycle among Wild and Domestic Mam-Mals in Three Areas of Orally Transmitted Chagas Disease Outbreaks. American Journal of Tropical Medicine and Hygiene, 79, 742-749.

[34] Pineda, S.A., Monfante, I., Santamaría, A., Gottdenker, N.L., Yabsley, M.J., Rapoport, G. and Calzada, J.E. (2011) Prevalence of Trypanosome Infections in Dogs from Chagas Disease Endemic Regions in Panama, Central America. Veterinary Parasitology, 178, 360-363. http://dx.doi.org/10.1016/j.vetpar.2010.12.043

[35] Moreno, M.L., Moretti, E., Basso, B., Céspedes, M.F., Catalá, S.S. and Gorla, D.E. (2010) Seroprevalence of Trypanosoma cruzi Infection and Vector Control Activities in Rural Communities of the Southern Gran Chaco (Argentina). Acta Tropicaica, 113, 257-262. http://dx.doi.org/10.1016/j.actatropica.2009.11.007

[36] Gürtler, R.E., Kitron, U., Cecere, M.C., Segura, E.L. and Cohen, J.E. (2007) Sustainable Vector Control and Management of Chagas Disease in the Gran Chaco, Argentina. Proceedings of the National Academy of Sciences of the United States of America, 104, 1619416199. http://dx.doi.org/10.1073/pnas.0700863104

[37] Romaña, C.A., Brunstein, D., Collin-Delavaud, A., Sousa, O. and Ortega-Barría, E. (2003) Public Policies of Development in Latin America and Chagas' Disease. Lancet, 362, 579. http://dx.doi.org/10.1016/S0140-6736(03)14132-3

[38] Barbabosa-Pliego, A., Díaz-Albiter, H.M., Ochoa-García, L., Aparicio-Burgos, E., LópezHeydeck, S.M., Velásquez-Ordoñez, V., Fajardo-Muñoz, R.C., Díaz-González, S., De OcaJimenez, R.M., Barbosa-Mireles, M., Guzmán-Bracho, C., Estrada-Franco, J.G., Garg, N.J. and Vázquez-Chagoyán, J.C. (2009) Trypanosoma cruzi Circulating in the Southern Region of the State of Mexico (Zumpahuacan) Are Pathogenic: A Dog Model. American Journal of Tropical Medicine and Hygiene, 81, 290-295.

[39] Ruiz-Piña, H.A. and Cruz-Reyes, A. (2002) The Opossum Didelphis virginiana as a SynanThropic Reservoir of Trypanosoma cruzi in Dzidzilché, Yucatán, México. Memórias do Instituto Oswaldo Cruz, 97, 613-620.

[40] Solís-Franco, R.R., Romo-Zapata, J. and Martínez-Ibarra, J.A. (1997) Wild Reservoirs Infected by Trypanosoma cruzi in the Ecological Park "El Zapotal", Tuxtla Gutiérrez, Chiapas, México. Memórias do Instituto Oswaldo Cruz, 92, 163-164. http://dx.doi.org/10.1590/S0074-02761997000200006

[41] Villagrán, M.E., Martínez-Ibarra, J.A. and de Diego, J.A. (2011) Pathological Alterations 
and Prevalence of Trypanosoma cruzi in Opossums from Western Mexico. Boletín de Malariología y Salud Ambiental, 51, 87-88.

[42] Urdaneta-Morales, S. and Nironi, I. (1996) Trypanosoma cruzi in the Anal Glands of Urban Opossums: I-Isolation and Experimental Infections. Memórias do Instituto Oswaldo Cruz, 91, 399-403. http://dx.doi.org/10.1590/S0074-02761996000400002

\section{Submit or recommend next manuscript to SCIRP and we will provide best service} for you:

Accepting pre-submission inquiries through Email, Facebook, LinkedIn, Twitter, etc. A wide selection of journals (inclusive of 9 subjects, more than 200 journals)

Providing 24-hour high-quality service

User-friendly online submission system

Fair and swift peer-review system

Efficient typesetting and proofreading procedure

Display of the result of downloads and visits, as well as the number of cited articles

Maximum dissemination of your research work

Submit your manuscript at: http://papersubmission.scirp.org/

Or contact ojepi@scirp.org 